\title{
THE ANAGOGICAL UNDERSTANDING OF SCRIPTURAL SYMBOLS IN CORPUS DIONYSIACUM
}

\author{
Assist. Ph.D. Ionut CHIRCALAN, \\ Assistant in Theology, "Ovidius" University of Constanta, Constanta, ROMANIA, \\ Email: ionut.chircalan@365.univ-ovidius.ro
}

\begin{abstract}
Corpus Dionysiacum (CD) is known mostly, in modern times, for the philosophical terminology of Neoplatonic origin, for its borrowings from Proclus on the vision about evil and, for the unique way in Christianity to present the spiritual and material universe as an ontological downward spiral in triadic steps. Some scholars accuse its author of forgery to mask non-Christian teachings in a Christian shape. This skeptical reception of the mysterious writings eludes the scriptural and patristic sources used by the same author in an overwhelming percentage. Therefore, it is of interest for an objective perspective to take a look at these issues, before pronouncing a verdict. This short study gets a glimpse of the biblical heritage in $\mathrm{CD}$, highlighting the anagogical understanding of the scriptural symbols, an argument for the Christian milieu of the addressees of the writings and their author.
\end{abstract}

Keywords: Bible; symbols; anagogy; cataphatism; knowledge;

\section{INTRODUCTION}

Bible or Scriptures, as known in the Christian literature, is/are the written Revelation received from God in a human intellectual "body". They could be missing, as Saint John Chrysostom affirms ${ }^{1}$ if human beings would have followed the divine way letting it be guided spiritually by the Holy Spirit Himself, but because of our weakness, God made His words written, similar to, in a typical way, the Incarnation of His Beloved Unique Son "when the fullness of the time had come" (Galatians, 4: 4). That is why Jesus Christ urges us boldly: "search the Scriptures, for in them you think you have eternal life; and these are they which testify of Me." (John 5: 39). In the primary Church, the term "Scriptures" referred to the Old Testament, meanwhile, after the apostolic age, it started to include the four Gospels, the Acts of the Apostles, the epistles of Apostles Paul, Peter, James, Jude, and the book of Revelation. These are the canonical books that form the New Testament until today.

Faithful to this tradition and indebted greatly to it, the author of Corpus Dionysiacum $(C D)$ makes no exception from his contemporaries, placing the scriptural texts on top of any oracle or teaching. Moreover, there is a constant concern of the author of Corpus Dionysiacum to base the statements made, on scriptural references, either from the Old or New Testament, usually freely evoked. Before the $20^{\text {th }}$ century, the biblical citations or allusions in $C D$ were believed to be slightly reduced. It is Paul Rorem's merit to have indexed them, as exhaustively as possible ${ }^{2}$, and to publish them as an appendix to the modern English

\footnotetext{
${ }^{1}$ Philip Schaff (ed.), The homilies of S. John Chrysostom, Archbishop of Constantinople, on the Gospel of St. Matthew, part I, Hom. I-XXV, John Henry Parker, Oxford, 1843, p. 1.

2 Paul Rorem, Biblical and liturgical symbols within the Pseudo-Dionysian synthesis, vol. 71, Pontifical Institute of Mediaeval Studies, 1984, pp. IX and 12, note 4.
} 
translation made by Colm Luibheid. ${ }^{3}$ According to his research, $C D$ alludes to 34 books from the "older tradition" (5 of which are deuterocanonical) and 25 books from the "new testament". With rare exceptions, the author omits the name of the biblical books, not mainly to remain true to the pseudonym, "but his vagueness also results, perhaps intentionally, in a fluid and open-ended view of the scriptures"4.

If the typological use of the Scriptures in $C D$ is largely used, the anagogical understanding makes a step forward, especially in the commentaries of the holy sacraments in the Ecclesiastical Hierarchy $(E H)$. Similar approaches of the author are identifiable in the Celestial Hierarchy $(\mathrm{CH})$ and Letter 9 (Ep. 9).

\section{THE UPLIFTING UNDERSTANDING OF BIBLICAL SYMBOLS}

Whereas the apophatic theology represents the pinnacle of the knowledge of God, in both the 'negative' way of excluding any deficiency from divine attributes and in the mystical state of knowing God personally in the cloud of unknowing, there are still many other ways through which God communicates His presence, adapted to our nature of human beings: the created (spiritual and material) world, the theurgies (holy sacraments) and the symbolic theology (the scriptural symbols). The author of $C D$ even mentions some titles of treatises written on these themes, most of them not preserved, but from their resume, we can briefly see that their importance in the economy of the literary project was of similar weight as Mystical Theology or Divine Names.

After enumerating the spiritual attributes applicable to the divine Goodness, the author states that "these are not the only names for God favored by the scripture writers, these drawn from universal or individual acts of Providence or those provided for." There are still some others, the biblical symbols, based on the sense perception, forming the subject of The Symbolic Theology. Due to their simplicity in the eyes of the uninitiated, these types of names fall into the arcane discipline, remaining kept hidden in the sacred veils of the literal/historical sense.

Through their origin, biblical symbols are of the same quality as the spiritual names, as they are intended to direct the believer to the encounter with God in an accessible way. "Some, too, have their origin in spiritual visions which enlightened initiates or prophets in the holy places or elsewhere" ( $D N 1$ 597A). The benevolent Providence appealed to these symbolical images with the freedom of man in mind, to preserve it, as long as, only freely, human beings can have a personal relationship with the Triune God, as an answer to the ecstatic divine Eros. "One's freedom perfection depends on one's love for God; also, it consists of the union of the human will with the divine will in the name of Jesus Christ."

As a Christian thinker, $C D$ 's author points out now and again that the entire human nature is called to suffer the divine union, and to become able to receive the knowledgeexperience of the Goodness. The Synaxis (Liturgy) is the concrete proof that through material means the incarnated Son of God makes theosis accessible to illuminated human beings and, in turn, through prayer, illuminated believers ascend in communion to the spiritual uncreated

\footnotetext{
3 Colm Luibheid, Paul Rorem, Pseudo-Dionysius: the Complete Works, translation by Colm Luibheid, foreword, notes, and translation collaboration by Paul Rorem, preface by René Roques, introductions by Jaroslav Pelikan, Jean Leclercq, and Karlfried Froehlich, Paulist Press, 1987, 294 p.

${ }^{4}$ Paul Rorem, Biblical and liturgical, p. 15.

5 Dragoș Corneliu Bălan, "Omul modern între libertatea creştină şi libertatea filosofică [Modern Man between Christian Freedom and Philosophical Freedom]", Annals of the "Ovidius" University of Constanta - Political Science Series (AUOC-SP), vol. 3 (2006), p. 159.
} 
life of the Divinity. The biblical symbols from the readings and prayers, part of the liturgical frame, uplift the Christians beyond any conceptual understanding of God, preparing them "to perceive the "Sacred Mystery», the Holy Communion that is the very body and blood of our Lord Jesus Christ, which are offered to us as a gift for our deification.",

\section{SYMBOLS - VEHICLES TO THEIR INTELLIGIBLE SOURCES}

In general, the author of $C D$ expresses the belief that not only the sensible elements within the Holy Sacraments are meant to become transmitters of holiness, but the whole creation is projected by God to represent, in special ontological states, different revelations of the Divine in the world. This correspondence is based on the fact that God has imprinted the whole creation of rationality, sustaining the progress in knowledge and the strengthening in existence at each level. In this sense, each higher step of existence represents for the equal or immediately lower one a symbol, a face of the divine adapted to the level of understanding of the receiver, through which the latter acquires a higher knowledge of the greatness of God's mystery, accompanied, paradoxically, of a fuller meaning and a higher strength in existence. Thus, the Creator reveals Himself to the creatures in three concomitant states (DN 4 705B): linear (direct), spiral (hierarchical), and circular (by the unifying inner simplification of each personal existence and by the resemblance to the above divine model of unity). ${ }^{7}$

Since after the entry of sin into the world this communication of the material world with the angelic one, even at its lower steps suffered a diminution, God revealed Himself to the man in a more accessible way, more sensibly, through non-conforming, lowered images that are meant to be overcome so to reveal the spiritual dimension they render. Thus are the biblical symbols, the zoomorphic ( $C H 2$ 145A), and anthropomorphic (Ep. 9, 1113B) images of the angelic world described in the Holy Scriptures. They depict in an encrypted way a reality for which the human mind must prepare itself through a process of purification $(\mathrm{CH} 2$ $141 \mathrm{~A})$, acquiring the exercise of seeing beyond appearances. The author of the $C D$ mentions that sometimes the same symbols are used to describe different realities: created or uncreated.

Let us cite an eloquent passage from Letter 9 (Ep. 9, 1108C-1109A):

"We have therefore to run counter to mass prejudice and we must make the holy journey to the heart of the sacred symbols. And we must certainly not disdain them, for they are the descendants and bear the mark of the divine stamps. They are the manifest images of unspeakable and marvelous sights. It is not only the transcendent lights and the conceptual things - or, putting the matter more simply, the divine things - which are depicted in the various symbolic forms, as when, for instance, one describes the transcendent God as «fire» or when one describes the meaning of God's conceptual scriptures as «afire». It also is the case that the angelic ranks, conforming to God, intelligible and intelligent beings, are represented in diverse modes, with a great collage of forms and, among other ways, by way of figures of fire. This same image of fire takes on different meanings, depending on whether it refers to the God who transcends all conceptions, to the providential activities or reasons of God, or indeed to the angels themselves. In one instance one thinks under the heading of «cause», in another under the heading of «subsistence», in a third instance under the heading of «participation», and in other instances under other headings according to their contemplation and wise arrangement determines. For, of course, one cannot use sacred symbols haphazardly. They have to be explicated in whatever way that is appropriate to the causes, subsistences, powers, orders, and dignities of which

${ }^{6}$ Lucian Petroaia, "Canon for the reception of Holy Communion: theological meanings and iconographic meanings", Teologie și educație la Dunărea de Jos, XIII (13) 2014, p. 449.

${ }^{7}$ DN 4 704D-705B, DN $9916 \mathrm{C}$. 


\section{they are the revealing signs."}

Another category of symbols is that of the things in the world. They are the basic symbols but become quasi-opaque to the spiritual eyes covered by the impurities of the sin. Through their nutritional properties or through the other uses that man gives them to support his biological life, they send to the Source of life and existences, testifying about the uncaused and causal Cause of all. But they cannot communicate anything else if the man does not receive illumination from God for the cleansing of the passions. Only after that, they become more and more suggestive, more and more communicative of meanings, and finally revealing the divine works that created and sustain them through the will of the Holy Trinity.

The material symbols - creatures and at the same time objects - are perceived by human beings as insufficient, not enough meaningful, and show that the world is not the supreme reality, but a symbol of another one, depending on that one. Its connection with God is also stressed by the fact that used without Him in mind, all the forces of the world can be destructive. The property of the world as a symbol of a higher existence is so much claimed by its insecure existence, that world must be considered as created by that Supreme existence, "that - not being a symbol of another [superior reality] and not dependent on another [one] must be considered as uncreated". 9

As the reader can notice, in $C D$ 's author understanding, the names attributed to God, both scriptural or philosophical ones, are just means of prayer, ways to address to God to the intensity when His presence becomes perceivable in the silence of the mind (vovs). Thus, $C D$ 's author adopts a new perspective toward the encounter with the Divinity, radically different from the one of the Neoplatonic Academy. On one side, specific to the Neoplatonism of Damascius is the initiative of the man by oneself in the spiritual ascent, while, on the other hand, the humble attitude of $C D$ 's author is obvious. ${ }^{10}$ In his case, the human being is acting just as an invoker of Almighty God's benevolence, in a state of intense prayer, until He may show His mercy in a summit of intelligible silence. With these remarks, we arrive at the significance of the sacramental symbols in Liturgy.

\section{SYMBOLS - VEHICLES TO THEIR INTELLIGIBLE SOURCES}

The fact that the world has not completely lost its quality as a symbol indirectly proves that man, as its master, has not completely lost the image given through creation by God. The author of $C D$ argues that even demons have not completely lost their ontological angelic properties, for the evil they do by free will acts as a parasite that corrupts their existence without being able to annihilate it. In a way, they are also symbols, but virtual ones, because they have moved away from the work of good that could have made them current bearers and communicators of the uncreated divine light. The transfiguration of the creation from the state of a partial or virtual symbol into that of a perfected symbol can be accomplished only through its Creator who made it able to grow in resemblance to Him to infinity in dependence on Him or, in the case of personal existences, in free communion with Him.

Father Dumitru Stăniloae, the Romanian profound dogmatician, emphasizes the

\footnotetext{
${ }^{8}$ Colm Luibheid, Paul Rorem, Pseudo-Dionysius, p.284-285.

${ }^{9}$ Dumitru Stăniloae, Sfântul Dionisie Areopagitul. Opere complete și Scoliile Sfântului Maxim Mărturisitorul [Saint Dionysius the Areopagite. Complete Works and the Scholia of Saint Maximmus the Confessor], Paideia Publishing House, Bucharest, 1996, p. 128, note 89.

${ }^{10}$ Marilena Vlad, "Damascius and Dionysius on Prayer and Silence”, Platonic Theories of Prayer, Brill, 2016, p. 209.
} 
importance of this synergy of the created with the uncreated, emphasizing, at the same time, the harmful consequences at the cosmic level for the human person in case of failure. ${ }^{11} \mathrm{He}$ shows that the author of the $C D$, emphasizing the thirst of absolute of the creatures, considers it to be feasible since they have by creation the kinship of their meanings - as images of the truths above them (EH 4 477B). Most fully, as the foundation of any perfection, this occurred in the incarnate Son of God, in which the two realities - uncreated and created - are united in His one hypostasis in an "unmixed, unchanged, undivided, and inseparable" way.

Christ is our bridge to eternal life. If we ask Him, He comes with His works to sustain ours and is whole wherever He comes as a person (especially being a Divine Person) through every act of His. "He is in all things and sanctifies them all for us and sanctifies our works with which He unites His works. The universe becomes a symbol of His presence, it becomes holy. A neutral universe does not exist. If Christ is not in it, it is possessed by evil. He who does not see or feel Christ in the things of the world and his works is under the dominion of the evil one. Either man tends to holiness and, in this case, he is in connection with Christ, or he is under the dominion of the evil one. In neutrality can not be. That is why in the $C D$ things are considered on the one hand as symbols, and on the other hand as holy. That is why the Orthodox Church wants to sanctify all the things that the believer uses." 12

Of all the symbols, the most specials ones are those instituted for the salvation of man. "The miracles performed by Jesus Christ are primary forms of practice of the Holy Mysteries"13. The author of the CD calls them "the holiest symbols" (EH 3 440B, 5 505B) and sees them communicated with different depths, corresponding to the hierarchical step of those who share them and to the "intelligent sights" (CH 9 260C) or "divine" (DN 1 592B) or "mysterious" (Ep. 9, 1104B) that they acquired. They represent the coming of the uncreated into the created and, received with reverence $(E p .9,1108 \mathrm{C})$, raise man to another plane. The meanings of the symbols are thus infinite. This leads us to the fact that the ecclesiastical hierarchy is the full revelation of God and the angels.

There is such a close connection between the material, the spiritual, and the divine, that the powers of God may be called upon through prayer to fill some of the acts and sensible works more than they normally do. Through prayer, the sensible things are made communicating liturgical symbols of powers different from the creative and sustaining ones of creation in general. This shows that all the components of the cosmos have a correspondence with the divine, "an ability to represent sensibly and encompass Him more and more, to be shaped and penetrated by the divine. All can be sanctified through the intercession of divine works. The whole universe is transfigurable, destined for deification, an environment over which and in which divine light can extend.

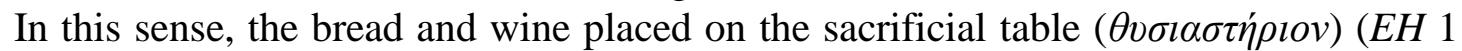
$425 \mathrm{~B}$ ) to be filled with the hidden presence of the Body and Blood of Christ must be understood as representing, in summary, the whole cosmos that God gave to us for our existence. By offering them to God as a gift of thanksgiving, believers express total openness to share in the presence of Christ, previously emptied of all egotistical power. Christ is in a state of Sacrifice and embraces us as we partake of Him, empowering us to offer ourselves to God the Father, the Cause of all.

\footnotetext{
${ }^{11}$ Dumitru Stăniloae, Sfântul Dionisie Areopagitul, p. 128, note 89.

${ }_{12}$ Dumitru Stăniloae, Sfântul Dionisie Areopagitul, p. 129, note 89.

${ }^{13}$ Nicuşor Tucă, Dragoș Corneliu Bălan, "Reconstitutions of the evangelical text in the Mysteries of the Orthodox Church", Dialogo, 2 (1) 2005, p. 100.
} 


\section{CONCLUSION}

The scriptural symbols taken from the material realities, as $C D$ affirms, are images of the spiritual realities able to prepare the human mind to receive the Highest Reality of all, Jesus Christ, the incarnated God. In a more complex way, from the beginning of the world, the entire universe represents, therefore, a sensible symbol of the uncreated gifts of God and a statement of its Creator. Even in Church times, these biblical symbols keep their utility, acting as a shelter for the childish spiritual eyes of the ones uninitiated. Meanwhile, the same symbols uplift the other ones, illuminated in the sacrificial divine love, to suffer the divine apophatically (personally), beyond any concept or imagination.

Through the Holy Communion, based on the Incarnation, Sacrifice, Resurrection and Glory of Christ, we, as Christians, receive symbolically (for the eyes) and realistically (for the soul) a foretaste of the Divine, of God Himself, made accessible to our weakness, rejoicing of the Goodness which God has prepared from eternity and for eternity to those which tend to resemble Him.

\section{BIBLIOGRAPHY:}

[1] Bălan, Dragoș Corneliu, "Modern Man between Christian Freedom and Philosophical Freedom”, in Annals of the „Ovidius” University of Constanta - Political Science Series (AUOC-SP), vol. 3 (2006), pp. 159-172.

[2] Luibheid, Colm, Rorem, Paul, Pseudo-Dionysius: the Complete Works, translation by Colm Luibheid, foreword, notes, and translation collaboration by Paul Rorem, preface by René Roques, introductions by Jaroslav Pelikan, Jean Leclercq, and Karlfried Froehlich, Paulist Press, 1987.

[3] Petroaia, Lucian, "Canonul pentru primirea Sfintei Împărtășanii: semnificații teologice și sensuri imnografice [Canon for the reception of Holy Communion: theological meanings and iconographic meanings]”, in Teologie și educație la Dunărea de Jos, XIII, 13 (2014), pp. 449-475.

[4] Rorem, Paul, Biblical and liturgical symbols within the Pseudo-Dionysian synthesis, vol. 71, Pontifical Institute of Mediaeval Studies, 1984.

[5] Schaff, Philip (ed.), The homilies of S. John Chrysostom, Archbishop of Constantinople, on the Gospel of St. Matthew, part I, Hom. I-XXV, John Henry Parker, Oxford, 1843.

[6] Stăniloae, Dumitru, Sfântul Dionisie Areopagitul. Opere complete şi Scoliile Sfântului Maxim Mărturisitorul [Saint Dionysius the Areopagite. Complete Works and the Scholia of Saint Maximmus the Confessor], Paideia Publishing House, Bucharest, 1996.

[7] Tucă, Nicușor, Bălan, Dragoș Corneliu, "Reconstitutions of the evangelical text in the Mysteries of the Orthodox Church", in Dialogo, 2 (1) 2005, pp. 100-111, DOI: $10.18638 /$ dialogo.2015.2.1.10.

[8] Vlad, Marilena, "Damascius and Dionysius on Prayer and Silence", in Platonic Theories of Prayer, Brill, 2016, pp. 192-212, https://doi.org/10.1163/9789004309005_012 